Reprint $^{1}$

Received: 10.09.2015.

Jochen Vollmann², Institut für Medizinische Ethik und Geschichte der Medizin, Ruhr-Universität Bochum, Germany*

\title{
Personalised medicine: Priority setting and opportunity costs in European public health care systems
}

\begin{abstract}
"Personalised medicine" is currently attracting considerable attention and raising high hopes and expectations in modern medicine. The term "personalised medicine" denotes the use of genetic or other biomarker information, and it does not focus on a more personal patient-doctor relationship. Furthermore, personalised medicine is associated with ethical problems like priority setting and opportunity costs in solidarity-based public health care systems. Personalised medicine provides modern, highly specific and expensive diagnostics and treatments, which serve only limited subgroups of patients. At the same time, research in other fields of clinical medicine, which could be of benefit to more patients than such limited subgroups, remain underfunded.
\end{abstract}

Key words: Personalised medicine, Person, Priority setting, Opportunity costs, Health economics

1 Reprinted by permission of the Publishers from 'Personalised medicine: priority setting and opportunity costs in European public health-care systems', in The Ethics of Personalised Medicine eds. Jochen Vollmann, Verena Sandow, Sebastian Wäscher and Jan Schildmann (Farnham: Ashgate, 2015), pp. 245-256. Copyright ( 2015

2 Major parts of this article were previously published in German (Jochen Vollmann: Persönlicher - besser kostengünstiger? Kritische medizinethische Anfragen an die "personalisierte Medizin". Ethik in der Medizin 25: 205-214 (2013) and in English (Jochen Vollmann: Personalised medicine: Priority setting and opportunity costs in European public health care systems in: Vollmann J, Sandow V, Wäscher S, Schildmann J (eds): Personalised Medicine: Ethical, Medical, Economic and Legal Critical Perspectives. Series: Medical Law and Ethics, Ashgate Publishers, Farnham 2014

* Contact address: Prof. Dr. med. Dr. phil. Jochen Vollmann, Institut für Medizinische Ethik und Geschichte der Medizin, Ruhr-Universität Bochum, Malakowturm - Markstr. 258a, 44799 Bochum, Germany, Tel. +49-34-3223394, Fax: +49-234-32-14205, e-mail: jochen.vollmann@rub.de 


\section{Introduction}

Modern medicine now has access to extensive genetic information about humans. In the international Human Genome Project the entire human genome was decoded, and technical progress in the field of sequencing technologies enables inexpensive analyses of the complete genome of an individual. Clinical medicine is seeking to utilise these insights from molecular genetics research to treat patients more effectively. In the field of medical diagnostics and treatment, knowledge about the individual genes of a patient is being used to develop custom-tailored, individualised treatments (Chin et al. 2011; McDermott et al. 2011; Phimister et al. 2012; Sledge 2012). For instance, by determining specific genetic biomarkers in a patient prior to starting treatment, doctors can determine whether or not a cancer drug will be effective against a specific tumour. Ineffective treatments can be excluded from the outset, and patients can therefore also be spared unnecessary adverse side effects. Furthermore, the pharmaceutical industry contends that by avoiding ineffective treatments, considerable health care costs can be saved (Richter-Kuhlmann 2012a).

This concept of personalised medicine is not only often used in oncology, but also raises hopes of successful treatments for other common diseases, such as cardiovascular diseases, type 2 diabetes mellitus and mental disorders. Frequently, personalised medicine is used as a synonym for progress and the promise of modern medicine per se and is presented in an uncritically positive way in research, business and the media (Collins 2011; Holsboer 2011; Schwan 2013). Public research funding has declared personalised medicine to be a priority both at the European and also at the national level (Bundesministerium für Bildung und Forschung 2010), and large pharmaceutical and biotechnology companies invest billions of euros into this research. Due to new scientific insights and the close cooperation of research, clinics and industry (Collins 2011; Hüsing 2010; Mirnezami et al. 2012), modern medicine is facing a new "revolution" (Richter-Kuhlmann 2012a). The treatment concept also appeals to medical laypersons, as something that is worthy of support. However, are the hopes associated with personalised medicine wellfounded, and are the high investments justified?

\section{The concept of a person and "personalised medicine"}

The term "personalised medicine" insinuates a kind of medical care which focuses on the health situation and the particular needs of each individual person. This is incorrect and misleading in two ways. First, the molecular genetic complexity of many illnesses makes the possibility of a treatment custom-tailored to each 
individual person very improbable, while the extremely high efforts and costs of this approach do not appear feasible in the current health care system. What the term connotes is therefore not personalised diagnosis and treatment but at best diagnostic and therapeutic approaches which are targeted at specific patient subgroups, for example, groups which have the same tumour biomarkers (stratified medicine).

Second, medical care focused on molecular genetic characteristics has nothing to do with medical care oriented on the individual patient. Individualisation only takes place at the molecular genetic level, but not at the personal level between doctor and patient. To achieve a personal treatment, the person of the patient should be placed at the centre of treatment, and this is exactly what so-called personalised medicine does not do (Dabrock et al. 2012; Hüsing 2010). A person is not only distinguished by biological traits, but also by individual psychological and social characteristics and needs. Individuals have their own lifestyles, values and preferences (Yurkiewicz 2010). Law and ethics emphasise the normative implications of the concept of personhood, as evident in ongoing debates about so-called "personhood" (Lampe 1998; Mahowald 1995). As a consequence, in the doctorpatient relationship the patient is entitled to adequate education and information by the doctor and has the individual right to consent to or to refuse a treatment (Kohnen et al. 2012). The patient's self-determined decision must be respected, even if it goes against the doctor's advice and against a medical indication, precisely because we ascribe the person these rights (Vollmann 2008).

This ethical and anthropological understanding of the "person" is expressed by many people in their wishes towards modern medicine. Patients wish to be perceived by their doctors and by medical institutions as individual persons with questions, wishes and normative preferences. In the citizens' report "High-Tech Medicine What Kind of Health Care Do We Want?" of the German Federal Ministry of Education and Research, citizens demand that medical and nursing staff have better communication skills. Furthermore, alongside the specialist subjects, mental and interpersonal aspects in day-to-day patient care must play an equal role in medical and nursing education and training and in research. The importance of taking time for the patient should be rediscovered in modern medicine ((Bundesministerium für Bildung und Forschung 2011; cf. also (Koch 2012; Siegmund-Schultze 2011)). This broader cultural understanding of the term "person" and the wishes of citizens for personal medical care are not considered in so-called personalised medicine. The term sounds appealing but is misleading. The intention of the inappropriate use of the term "person", which is conveyed in numerous texts and images in advertising materials, is to achieve a positive image and wide acceptance in society. It is important to debunk this questionable advertising strategy because it abuses the 
concept of personhood, perceives patients primarily as carriers of molecular genetically determined traits, suggests a genetic determinism for medicine (Kerr und Cunningham-Burley 2000; Tauber und Sarkar 1993) and aims at setting specific priorities in research funding. The latter, in particular, requires a transparent and critical discussion, as well as democratic decision-making.

\section{Basic research and clinical application}

Additional doubts arise with regard to the statement of the U.S. Food and Drug Administration (FDA) that after a decade of billions of dollars in investments in the Human Genome Project and in subsequent genetic analysis studies, the yield has only been a small number of clinical treatments on the basis of genetic biomarkers (Hüsing 2010; Marshall 2011). In addition, for the president of the Max Planck Society, the hope of immediately deriving rapid medical progress from the deciphering of the human genome has hardly been fulfilled (Gruss 2011). Upon closer scientific observation the reason for this discrepancy is clear. The clinical applications that have been successful until now are mainly in the field of oncology and are limited to a few tumour types for which the molecular genetic biomarkers are known and for which there is a treatment available. This fortunate constellation is the exception in clinical practice; for the majority of patients these new treatments are of no benefit. The scientific explanation for the slow clinical progress lies in the complexity of tumour biology, where the variability and mutation dynamics of the genetic traits of many tumours complicate the development of targeted therapies. Progress in clinical treatment and practice does not necessarily follow from a brilliant treatment approach that is derived from basic research (Browman et al. 2011; Burke und Psaty 2007; Konstantinopoulos et al. 2009; Ludwig 2012). Unfortunately, the international experience during the last decade makes rapid clinical progress for the majority of cancer patients very unlikely.

\section{Medical research and industry under pressure to succeed}

This sobering conclusion is contrary to the euphoria about the promise of personalised medicine. After decades without innovation breakthroughs, many biomedical researchers long for significant therapeutic progress (Collins 2011; Holsboer 2011; Hudson 2009). The pharmaceutical industry is in a similar situation - its patents for the strongest selling drugs (so-called "blockbusters") are due to expire in the coming years, and many companies do not have any new innovative drugs in their development pipeline (Collier 2011; Greiner 2012). Rather, the 
pharmaceutical and biotechnology industries are under pressure from the markets to reduce their high costs for research and development, since these, given the lack of innovation, do not refinance themselves (Aiolfi 2011; Dhankhar et al. 2012; Hunt et al. 2011; KPMG 2011). Compared to the stock price development of other companies, the value of many pharmaceutical companies has declined, while the return on investment from the high expenditures in research and development has been falling for years. As a result, consultants predict tough times ahead for the pharmaceutical industry (Frankfurter Allgemeine Zeitung 2012).

In this difficult economic situation, many pharmaceutical companies are counting on rapid progress in the new field of personalised medicine. However, the high expectations are contrasted by the sluggish progress in the clinical application of personalised medicine (Ludwig 2012). In practice, there is a danger that insufficiently tested drugs might be introduced too hastily into clinical care. New "personalised" diagnostics and therapeutics may not have been approved without sufficient proof of their effectiveness. However, validation studies that are required for scientific proof of effectiveness are seldom carried out because these are longterm, complex and costly (Ludwig 2012). It is commonly argued that, in personalised medicine, the relevant cost and time-consuming proof of effectiveness does not apply and should be abbreviated to get approval for the drug. But even in small patient groups and targeted treatments, the effectiveness and benefit of new drugs must be scientifically proven to ensure the health and welfare of the patients and to avoid unnecessary health costs (Ludwig et al. 2009; Richter-Kuhlmann 2012a).

For this reason, drugs in the field of personalised treatments must be checked according to normal approval procedures, in order to meet scientific and therapeutic standards. Since current clinical research in the field of personalised medicine is primarily financed by the pharmaceutical industry, conflicts of interest are inevitable (Valachis et al. 2012). To promote the necessary gain in scientific knowledge in this new field, we therefore need more clinical research that is publically funded and is independent from the private sector. This would strengthen serious patient-oriented clinical research that is independent of short-term economic interests (Vollmann et al. 2011). At present, however, universities and other public research organisations in this field are hardly autonomous and independent, so that the content of research activities and research strategies are often heavily influenced by industry (Dreger 2011). 


\section{Priority setting and opportunity costs}

The high investment costs in research based on molecular genetic criteria raise the question of opportunity costs. This type of research ultimately provides stratified medical care that only benefits subgroups of patients. Investments in this field have been made for more than a decade and, due to many open research questions, will continue to be made in the future (Rauprich 2010). Given the limited resources in the health care sector, a prioritisation decision is required already at the research level regarding the extent of public resources that shall flow into particular areas of the health care system. A research priority in one area limits the remaining research funds for other medical specialty areas. With regard to the promotion and funding of personalised medicine, this difficult normative and political decision is further exacerbated since there are only a relatively small number of patients who may benefit from these very expensive measures. That is why clinical physicians are concerned that through the prioritised promotion of personalised medicine, other important clinical and health care areas which might be beneficial for many patients will be neglected (Browman et al. 2011; Koch 2012; Ludwig 2012; SiegmundSchultze 2011). Thus far, only a minority of patients have benefited from this expensive, research- and economics-driven project of personalised medicine (Browman et al. 2011; Deutscher Ethikrat [German Ethics Council] 2012; Hamburg und Collins 2010). Based on previous experience, high profits can be expected from expensive cancer drugs for small patient groups (so-called "niche busters"), and therefore this approach continues to appear lucrative for the pharmaceutical industry, without taking into account the health needs of the majority of patients in our health care system.

Whereas in oncology at least a small portion of patients have benefited from the innovations of personalised medicine, they have until now brought no benefit for patients in other social and medically important disease groups. For example, for the common disease type 2 diabetes, all molecular genetic descriptions of subgroups, biomarkers, etc. are not superior to the usual preventive, diagnostic and treatment options and do not improve the health situation of the affected patients (Schulze 2011). Moreover, screening for type 2 diabetes does not offer any relevant advantages (Simmons et al. 2012). Rather, as our society ages, our nutrition, exercise and lifestyle play an increasingly crucial role in the prevention and treatment of type 2 diabetes (Kurth 2012; Richter-Kuhlmann 2012b). For this disease, modern medicine does not primarily require new molecular genetic insights but rather socio-medical care approaches and intensive public health research to enable and support at-risk and affected people to adopt healthy behaviours as individuals. But this research is seriously underfunded in our health care system. 
Another example is the increasing importance of mental illness as a public health concern in our society. Mental illness and its treatment and prevention is of great significance for affected patients, health insurance companies, pension fund insurance companies who bear the cost for rehabilitation and for the labour market. According to the German Federal Ministry of Labour and Social Affairs, the missed days at work due to mental disorders have increased from $6.6 \%$ in 2001 to $13.1 \%$ in 2010, which is associated with economic costs of approximately EUR 8 - 10 billion annually. The most important specified causes are higher demands at the workplace, increased personal responsibility, pressure to be flexible, irregular employment relationships and job insecurity (Deutsches Ärzteblatt 2012). The current care of these patients in our health care system is under criticism due to excessively long sick leave times, also excessive waiting times for psychiatric and psychotherapy treatment and/or inpatient rehabilitation measures, and too frequent early retirements due to mental disorders. Investments are therefore required in research to develop new concepts for social-psychiatric prevention and treatment, thus, for example, enabling effective prevention and early intervention at the workplace and improving the cooperation between the company doctor, primary care physician, psychiatrist and hospital, etc. This raises the issue whether we as a society shall respond to the increasing importance of mental illness primarily with high investments in molecular genetic research for "personalised treatment" or invest at least in equal measure in social psychiatric and mental health research, which in current research policy is allocated relatively few funds.

Therefore, from a medical ethics perspective, the existing preference for molecular genetics medicine in personalised medicine in contrast to other research fields in the publically funded health care system needs to be critically examined. In essence, all prioritisation decisions are ethical decisions in which competing values must be weighed (Rauprich 2010). In doing so, transparency must prevail regarding who decides about what facts, which criteria are used and on which arguments decisions are based. Therefore, it is ethically unacceptable that influential individual interests de facto determine medical research priorities and resource allocation in the publiclaly funded health care system. But this is exactly what is currently happening under the innocuous label of "personalised medicine". Cost-benefit assessments of the individual treatments - now often discussed - are also insufficient, since, on the basis of empirical data, they only allow statements about the medical benefits and the costs of the treatment area under investigation. Frequently in practice, the selection of the treatment area for research already represents a setting of priorities within the overall spectrum of possible health-promoting measures, without prior reflection on the norms involved. For our health care in the future, what is required 
are transparent and democratically legitimised superordinate medical and research policy prioritisations.

However, our society leaves crucial research policy decisions to internationally active stakeholders from research and industry. Whereas public funds have invested heavily in basic research (e.g. Human Genome Project), in the field of clinical applications priority setting is left to the discretion of international pharmaceutical industry. In Germany, universities and other public research organisations have little influence on content prioritisation in this field because, as I noted above, due to the lack of public funding, independent research hardly exists. To be sure, cooperation with the public health authorities is always emphasised in order to coordinate health care and socio-economic priorities. In reality, however, this plays hardly a role. The reason is that international pharmaceutical companies develop diagnostics and drugs for the world market (Dhankhar et al. 2012; Frankfurter Allgemeine Zeitung 2013; Hunt et al. 2011; KPMG 2011; Schwan 2013). However, the health care needs and the financing of the health care systems differ greatly in the various countries. For example, the currently still largest health care market in the U.S., with its strong private sector orientation and a high proportion of citizens who lack medical insurance, differs greatly from European health care systems. The demographic trend of Western societies contrasts sharply to that of the economically emerging countries such as Brazil and India, with their high proportion of young people in the population and a growing, upwardly mobile middle class that finances its medical care privately (Agarwal et al. 2012). In these so-called emerging markets, the pharmaceutical industry in 2020 will proportionately make equivalent profits as in the currently largest pharmaceutical market, the U.S. (KPMG 2011). And these profits will originate from innovative products, including products in the fields of personalised medicine, which are expensive and have to be paid for privately (Griggs 2009). By contrast, the importance of European health care markets for the development of new drugs is declining.

Given the different socio-economic and health priorities, which vary from country to country, the research and development investments of the pharmaceutical industry will follow international market opportunities, which are not necessarily congruent with health care needs in Germany and other European countries. To provide optimal health care for our population, it is essential to develop our own strategic research and health care policy in the public health sector. To achieve this, those responsible for health and research policy must recognise the existing problems and put them forward for public debate. However, past experience with a public discussion about setting priorities and rationing in the health care system in Germany gives little cause for optimism. A wealthy, shrinking and ageing society 
does not muster the strength to carry out a reform or to design its own public health system. Thus, society should not complain when global stakeholders set priorities under the lofty-sounding label of personalised medicine - priorities that do not correspond to the society's own health care needs.

\section{Conclusion}

Genetic biomarker-based personalised medicine does not contribute to a more personal treatment of individual patients, in contrast to patient- or person-centred medical care. Subgroups of patients, e. g. in oncology, may have medical advantages from the present progress in personalised medicine, but it is unlikely that this will be the case for the overall majority of patients. The promise of less expensive health care through personalised medicine lacks any empirical evidence. Rather, based on past experience, an increase of costs is more likely.

A public debate is needed on priority setting in medical research and treatment and about how societies and public health systems can influence the development of the research agenda regarding future health care priorities.

\section{Acknowledgements:}

This study was conducted in the research network "Personalised Medicine in Oncology: an Interdisciplinary Study on Ethical, Medical, Economical and Legal Aspects" (Grant project number: 01 GP 1001A), which is supported by the German Federal Ministry of Education and Research (BMBF).

\section{REFERENCES}

1. Agarwal, S; d'Almeida, J; Francis, T (2012) Capturing the Brazilian pharma opportunity. Global pharma companies are missing a chance to serve Brazil's increasingly prosperous and growing middle class. McKinsey Quarterly March 2012:1-4

2. Aiolfi, S (2011) Die Pharmaforschung ist zu teuer. Investoren zeigen sich irritiert über einen offensichtlichen Mangel an Effizienz. Neue Zürcher Zeitung, 31.12.2011

3. Browman, G; Hébert, PC; Coutts, J (2011) Personalized medicine: a windfall for science, but what about patients? Canadian Medical Association Journal 183:E1277

4. Bundesministerium für Bildung und Forschung (2010) Ideen. Innovation. Wachstum - HightechStrategie 2020 für Deutschland. Berlin: Bundesministerium für Bildung und Forschung 
5. Bundesministerium für Bildung und Forschung (2011) Bürgerreport: Hightech-Medizin - Welche Gesundheit wollen wir? Berlin: Bundesministerium für Bildung und Forschung

6. Burke, W; Psaty, BM (2007) Personalized medicine in the era of genomics. Journal of the American Medical Association 298:1682-1684

7. Chin, L; Andersen, JN; Futreal, PA (2011) Cancer genomics: from discovery science to personalized medicine. Nature Medicine 17:297 - 303

8. Collier, R (2011) Bye, bye blockbusters, hello niche busters. Canadian Medical Association Journal 183:E697-E698

9. Collins, FS (2011) Meine Gene - mein Leben. Heidelberg: Spektrum Akademischer Verlag

10. Dabrock, P; Braun, M; Ried, J (2012) Individualisierte Medizin: Ethische und gesellschaftliche Herausforderungen. Forum 27:209-213

11. Deutscher Ethikrat [German Ethics Council] (2012) Pressemitteilungen: Ethikrat rückt den Patienten in den Fokus der personalisierten Medizin. Berlin: Deutscher Ethikrat

12. Deutsches Ärzteblatt (2012) Krankschreibungen: Mehr Fehltage wegen psychischer Erkrankungen. Deutsches Ärzteblatt 109:A-948

13. Dhankhar, A; Evers, M; Møller, M (2012) Escaping the sword of Damocles: toward a new future for pharmaceutical R\&D. Chicago: McKinsey \& Company

14. Dreger, P (2011) Brief: Priorisierung in der Forschung. Deutsches Ärzteblatt 108:A-2286

15. Frankfurter Allgemeine Zeitung (2012) Im Gespräch: Thomas Strüngmann, Unternehmer und Investor in der Pharmabranche. Frankfurter Allgemeine Zeitung, 10.04.2012

16. Frankfurter Allgemeine Zeitung (2013) Sanofi schmerzt Patentauslauf. Gewinn des Pharmakonzerns könnte 2013 sinken. Frankfurter Allgemeine Zeitung, 08.02.2013

17. Greiner, W (2012) Ökonomische Herausforderungen der individualisierten Medizin. Forum 27:203208

18. Griggs, JJ (2009) Personalized medicine: a perk of privilege? Clinical Pharmacology \& Therapeutics $86: 21-23$

19. Gruss, P (2011) Der Faktor Mensch. MaxPlanckForschung 1:6-7

20. Hamburg, MA; Collins, FS (2010) The path to personalized medicine. New England Journal of Medicine 363(4):301-304

21. Holsboer, F (2011) Biologie für die Seele: Mein Weg zur personalisierten Medizin. München: dtv

22. Hudson, TJ (2009) Personalized medicine: a transformative approach is needed. Canadian Medical Association Journal 180:911-913

23. Hunt, V; Manson, N; Morgan, P (2011) A wake-up call for big pharma: pharmaceuticals \& medical products practice. McKinsey Quarterly December 2011:1-6

24. Hüsing, B (2010) Individualisierte Medizin - Potenziale und Handlungsbedarf. Zeitschrift für Evidenz, Fortbildung und Qualität im Gesundheitswesen 104:727-731

25. Kerr, A; Cunningham-Burley, S (2000) On ambivalence and risk: reflexive modernity and the new human genetics. Sociology 34:283-304

26. Koch, M (2012) Arzt-Patienten-Beziehung: In falsches Fahrwasser geraten. Deutsches Ärzteblatt 109:A20

27. Kohnen, T; Schildmann, J; Vollmann, J (2012) Patients' self-determination in "personalized medicine": the case of whole genome sequencing and tissue banking in oncology, Individualized medicine between hype and hope. Hg. P Dabrock; M Braun; J Ried. Zürich: Lit Verlag, 97-110

28. Konstantinopoulos, PA; Karamouzis, MV; Papavassiliou, AG (2009) Educational and social-ethical issues in the pursuit of molecular medicine. Molecular Medicine 15:60-63

29. KPMG (2011) Pharmaceuticals: Future pharma. Five strategies to accelerate the transformation of the pharmaceutical industry by 2020. London: KPMG 
30. Kurth, B-M (2012) Erste Ergebnisse aus der "Studie zur Gesundheit Erwachsener in Deutschland" (DEGS). Bundesgesundheitsblatt 55:980-990

31. Lampe, E-J (1998) Persönlichkeit, Persönlichkeitssphäre, Persönlichkeitsrecht, Persönlichkeit, Familie, Eigentum: Grundrechte aus der Sicht der Sozial- und Verhaltenswissenschaften. Hg. E-J Lampe. Opladen: Westdeutscher Verlag, 73-102

32. Ludwig, W-D; Fetscher, S; Schildmann, J (2009) Teure Innovationen in der Onkologie - für alle? Überlegungen zu Voraussetzungen für eine rationale Pharmakotherapie und ethische Herausforderungen. Der Onkologe 15:1004-1014

33. Ludwig, W-D (2012) Möglichkeiten und Grenzen der stratifizierenden Medizin am Beispiel von prädiktiven Biomarkern und "zielgerichteten" medikamentösen Therapien in der Onkologie. Zeitschrift für Evidenz, Fortbildung und Qualität im Gesundheitswesen 122:11-22

34. Marshall, E (2011) Waiting for the revolution. Science 331:526-529

35. McDermott, U; Downing, JR; Stratton, MR (2011) Genomics and the continuum of cancer care. New England Journal of Medicine 364:340-350

36. Mirnezami, R; Nicholson, J; Darzi, A (2012) Preparing for precision medicine. New England Journal of Medicine 366:489-491

37. Phimister, EG; Feero, GW; Guttmacher, AE (2012) Realizing genomic medicine. New England Journal of Medicine 366:757-759

38. Rauprich, O (2010) Rationierung unter den Bedingungen der Endlichkeit im Gesundheitswesen, Endliches Leben Interdisziplinäre Zugänge zum Phänomen der Krankheit. Hg. G Thomas; M Höfner; S Schaede. Tübingen: Mohr Siebeck, 229-256

39. Richter-Kuhlmann, E (2012a) Pränataldiagnostik: Paradigmenwechsel. Deutsches Ärzteblatt 109:A1306

40. Richter-Kuhlmann, EA (2012b) Gesundheitssurvey des Robert-Koch-Instituts: Zivilisationskrankheiten nehmen zu. Deutsches Ärzteblatt 109:C-1171-1172

41. Schulze, M (2011) Programme of the international symposium: predictive genetic testing, risk communication and risk perception: Value of genetic. Information for diabetes risk prediction. Berlin: Robert Koch Institut

42. Schwan, S (2013) Die Dividendenhoffnungen bleiben intakt. Frankfurter Allgemeine Zeitung, 14.01.2013

43. Siegmund-Schultze, N (2011) Versorgung von Krebspatienten: Menschliche Zuwendung aufwerten. Deutsches Ärzteblatt 108:A-932

44. Simmons, RK; Echouff o-Tcheugui, JB; Sharp, SJ et al. (2012) Screening for type 2 diabetes and population mortality over 10 years (ADDITION-Cambridge): a cluster-randomised controlled trial. Lancet 380:1741-1748

45. Sledge, GW (2012) The challenge and promise of the genomic era. Journal of Clinical Oncology 30:203209

46. Tauber, AI; Sarkar, S (1993) The ideology of the human genome project. Journal of the Royal Society and Medicine 86:537-540

47. Valachis, A; Polyzos, NP; Nearchou, A et al. (2012) Financial relationships in economic analyses of targeted therapies in oncology. Journal of Clinical Oncology 30:1316-1320

48. Vollmann, J (2008) Patientenselbstbestimmung und Selbstbestimmungsfähigkeit: Beiträge zur klinischen Ethik. Stuttgart: Kohlhammer

49. Vollmann, J; Schildmann, J; Kohnen, T (2011) Onkologie: Sehr gut recherchiert. Deutsches Ärzteblatt 108:A-2341

50. Yurkiewicz, S (2010) The prospects for personalized medicine. Hastings Center Report 40:14-18 


\title{
Jochen Vollmann
}

\section{Personalizirana medicina: postavljanje prioriteta i oportunitetni troškovi u europskim sustavima javnog zdravstva}

\section{SAŽETAK}

\begin{abstract}
"Personalizirana medicina” trenutno privlači veliku pozornost i podiže velike nade i očekivanja u modernoj medicini. Pojam "personalizirane medicine" označava korištenje genetskih ili drugih informacija biomarkera i time se udaljava od osobnog odnosa liječnik - pacijent. Nadalje, personalizirana medicina povezana je s etičkim problemima kao što su određivanje prioriteta i oportunitetni troškovi u sustavima javnog zdravstva utemeljenim na solidarnosti. Personalizirana medicina nudi moderne, vrlo specifične i skupe dijagnostike i liječenja, koja su korisna samo ograničenim podskupinama bolesnika. Istovremeno, istraživanja u drugim područjima kliničke medicine, koja bi mogla biti korisna svim bolesnicima,i dalje se nedovoljno financiraju.
\end{abstract}

Ključne riječi: personalizirana medicina, osoba, određivanje prioriteta, oportunitetni troškovi, ekonomija zdravlja 